\title{
Emergence of a novel GII.17 norovirus - End of the GII.4 era?
}

M de Graaf (m.degraaf@erasmusmc.nl)1 , J van Beek ${ }^{1,2}$, H Vennema ${ }^{2}$, A T Podkolzin³ , J Hewitt ${ }^{4}$, F Bucardo ${ }^{5}$, K Templeton $^{6}$, J Mans ${ }^{7}$, J Nordgren ${ }^{8}$, G Reuter ${ }^{9}$, M Lynch ${ }^{10}$, L D Rasmussen ${ }^{11}$, N Iritani ${ }^{12}$, M C Chan ${ }^{13}$, V Martella ${ }^{14}$, K Ambert-Balay $^{15}$, J Vinjé ${ }^{16}$, P A White ${ }^{17}$, M P Koopmans ${ }^{1,2}$

1. Erasmus MC, Department of Viroscience, Rotterdam, the Netherlands

2. Centre for Infectious Disease Control, National Institute for Public Health and the Environment (RIVM), the Netherlands

3. Central Research Institute of Epidemiology, Moscow, Russia

4. Institute of Environmental Science and Research, Porirua, New Zealand

5. Department of Microbiology, University of Leon, Nicaragua

6. Department of Medical Microbiology, Royal Infirmary of Edinburgh, Edinburgh, United Kingdom

7. Department of Medical Virology, Faculty of Health Sciences, University of Pretoria, Pretoria, South Africa

8. Division of Molecular Virology, Department of Clinical and Experimental Medicine, Linköping University, Sweden

9. Regional Laboratory of Virology, National Reference Laboratory of Gastroenteric Viruses, ÁNTSZ Regional Institute of State Public Health Service, Pécs, Hungary

10. Department of Microbiology, Mater Misericordiae University Hospital, Dublin, Ireland

11. Virology Surveillance and Research Section, Microbiological Diagnostics and Virology, Statens Serum Institut, Denmark

12. Department of Microbiology, Osaka City Institute of Public Health and Environmental Sciences, Tennoji-ku, Osaka, Japan

13. Department of Microbiology, Chinese University of Hong Kong, China

14. Faculty of Veterinary Medicine, Università Aldo Moro di Bari, Valenzano, Italy

15. National Reference Center for Enteric Viruses, Laboratory of Virology, CHU of Dijon, Dijon, France

16. Division of Viral Diseases, National Center for Immunizations and Respiratory Diseases, Centers for Disease Control and Prevention, Atlanta, GA, United States

17. School of Biotechnology and Biomolecular Sciences, Faculty of Science, University of New South Wales, Sydney, Australia

\section{Citation style for this article:}

de Graaf M, van Beek J, Vennema H, Podkolzin AT, Hewitt J, Bucardo F, Templeton K, Mans J, Nordgren J, Reuter G, Lynch M, Rasmussen LD, Iritani N, Chan MC, Martella V, Ambert-Balay K, Vinjé J, White PA, Koopmans MP. Emergence of a novel Gll.17 norovirus - End of the Gll.4 era?. Euro Surveill. 2015;20(26):pii=21178. Available online: http://www.eurosurveillance.org/ViewArticle.aspx?Articleld=21178

In the winter of 2014/15 a novel GII.P17-GII.17 norovirus strain (GII.17 Kawasaki 2014) emerged, as a major cause of gastroenteritis outbreaks in China and Japan. Since their emergence these novel GII.P17-GII.17 viruses have replaced the previously dominant GII.4 genotype Sydney 2012 variant in some areas in Asia but were only detected in a limited number of cases on other continents. This perspective provides an overview of the available information on GII.17 viruses in order to gain insight in the viral and host characteristics of this norovirus genotype. We further discuss the emergence of this novel GII.P17-GII.17 norovirus in context of current knowledge on the epidemiology of noroviruses. It remains to be seen if the currently dominant norovirus strain GII.4 Sydney 2012 will be replaced in other parts of the world. Nevertheless, the public health community and surveillance systems need to be prepared in case of a potential increase of norovirus activity in the next seasons caused by this novel GII.P17-GII.17 norovirus.

In this issue of Eurosurveillance, observations from Japan are reported on an unusual prevalence of a previously rare norovirus genotype, GII.17, in diarrheal disease outbreaks at the end of the 2014/15 winter season [1], similar to what was observed for China $[2,3]$. Norovirus is a leading cause of gastroenteritis [4].
Although the infection is self-limiting in healthy individuals, clinical symptoms are much more severe and can last longer in immunocompromised individuals, the elderly and young children $[5,6]$.

The Norovirus genus comprises seven genogroups (G), which can be subdivided in more than 30 genotypes [7]. Viruses belonging to the GI, GII and GIV genogroups can infect humans, but since the mid-1990s Gll.4 viruses have caused the majority (ca 70-80\%) of all norovirus-associated gastroenteritis outbreaks worldwide [8-10].

Gll.4 viruses can continue to cause widespread disease in the human population because they evolve through accumulations of mutations into so-called drift variants that escape immunity from previous exposures [11]. Contemporary GII.4 noroviruses also demonstrate intra-genotype recombination near the junction of open reading frame (ORF) 1 and ORF2, which is likely to foster the emergence of novel Gll.4 variants [12]. In addition, the binding properties of Gll.4 viruses have altered over time, resulting in a larger susceptible host population [13]. 


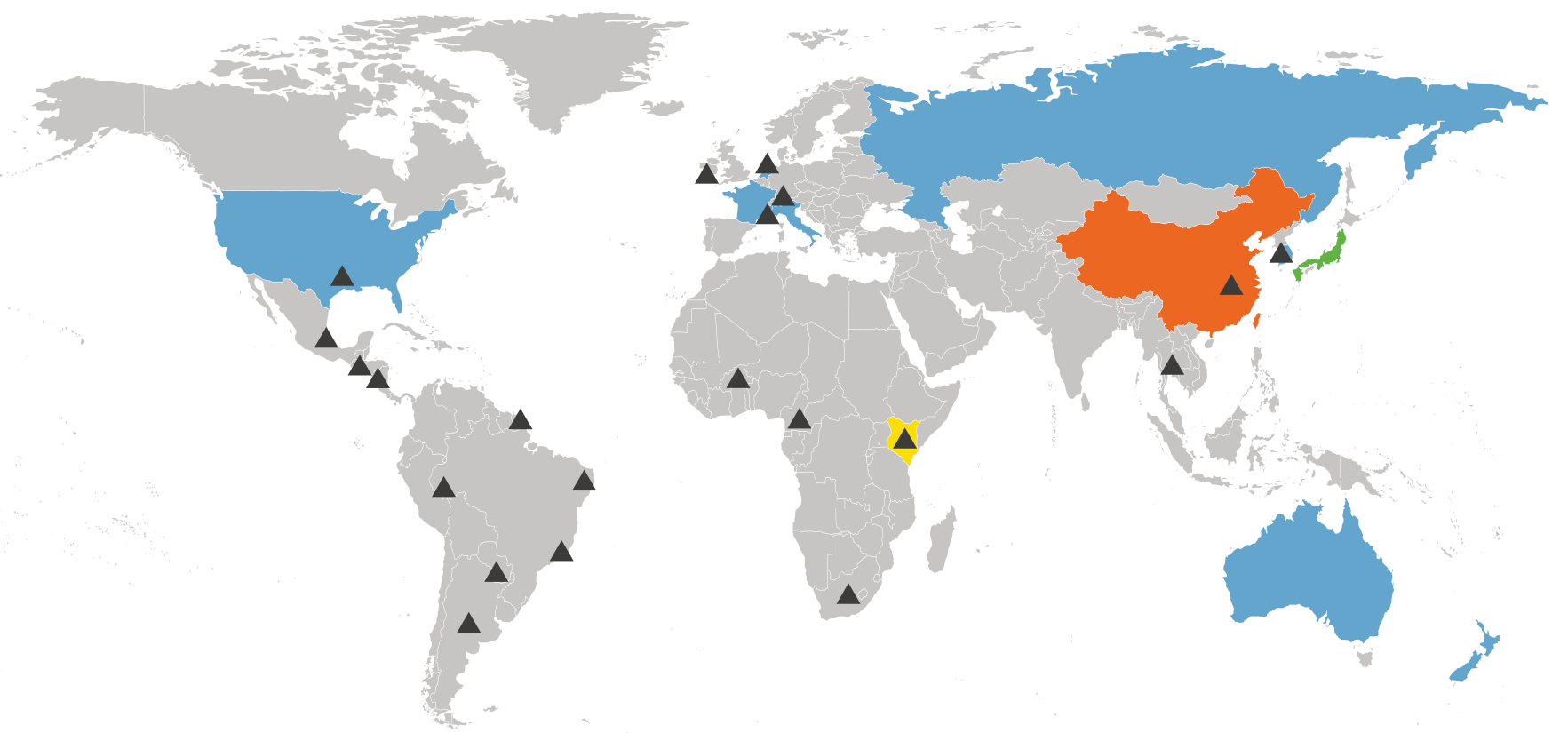

Detection of the novel GII.17 virus in environmental samples

Sporadic detection of the novel Gll.17 virus

The novel GII.17 is the predominant genotype

Major outbreaks of the novel GIl.17 virus

Sporadic detection of Gll.17 viruses from before the emergence of the novel GIl.17 virus

\section{Emergence and geographical spread of GII.17 genotype noroviruses} Viruses of the Gll.17 genotype have been circulating in the human population for at least 37 years; the first GII.17 strain in the National Center for Biotechnology Information (NCBI) databank is from 1978 [14]. Since then viruses with a Gll.17 capsid genotype have sporadically been detected in Africa, Asia, Europe, North America and South America (Table, Figure 1). The virus appears to be clinically relevant, as it has been associated with acute gastroenteritis (AGE) in children and adults, and with chronic infection in an immunocompromised renal transplant patient [15] and a leukaemia patient (unpublished data). In the United States (US), only four Gll.17 outbreaks were reported between 2009 to 2013 through CaliciNet, with a median of 11.5 people affected by each outbreak [16]. In Noronet, an informal international network of scientists working in public health institutes or universities sharing virological, epidemiological and molecular data on norovirus, GII.17 cases were also sporadically reported in Denmark and South Africa during this period [17].

More widespread circulation of GII.17 was first reported for environmental samples in Korea from 2004 to 2006. This information was published in a report in 2010 by the Korean Food and Drug Administration (KFDA) and was cited by Lee et al. [18], but the original document describing this finding is not publicly available and there are no matching clinical reports. From 2012 to 2013 a novel Gll.17 virus accounted for $76 \%$ of all detected norovirus strains in rivers in rural and urban areas in Kenya [19]. In the winter of $2014 / 15$, genetically closely related GII.17 viruses were first detected in AGE outbreaks in the Guangdong province in China in schools, colleges, factories and kindergartens [3]. Sequence analyses demonstrated that 24 of the 29 reported outbreaks during that winter were caused by GII.17. A large increase in the incidence of AGE outbreaks was also reported; 29 outbreaks associated with 2,340 cases compared with nine outbreaks and 949 cases in the previous winter when Gll.4 Sydney 2012 still was the dominant genotype [3].

During the same winter there was also an increase in outbreak activity in Jiangsu province, which could be attributed to the emergence of this novel GII.17 [2]. This triggered us to investigate the prevalence of GII.17 in other parts of the world by means of a literature study and by inviting researchers collaborating within Noronet to share their data on GII.17. Currently, in Asia, in addition to Guangdong and Jiangsu $[2,3]$, the novel GII.17 is also the predominant genotype in Hong Kong (unpublished data) and Taiwan [20], while in Japan, a sharp increase in the number of cases caused by this novel virus has been observed during the 2014/15 winter season [1]. Related viruses have been detected sporadically in the US [21] (http://www.cdc.gov/norovirus/reporting/calicinet/index.html), Australia, France, Italy, Netherlands, New-Zealand and Russia (unpublished data, www.noronet.nl) (Figure 1). In France the novel Gll.17 virus appeared at the beginning of 2013 , 


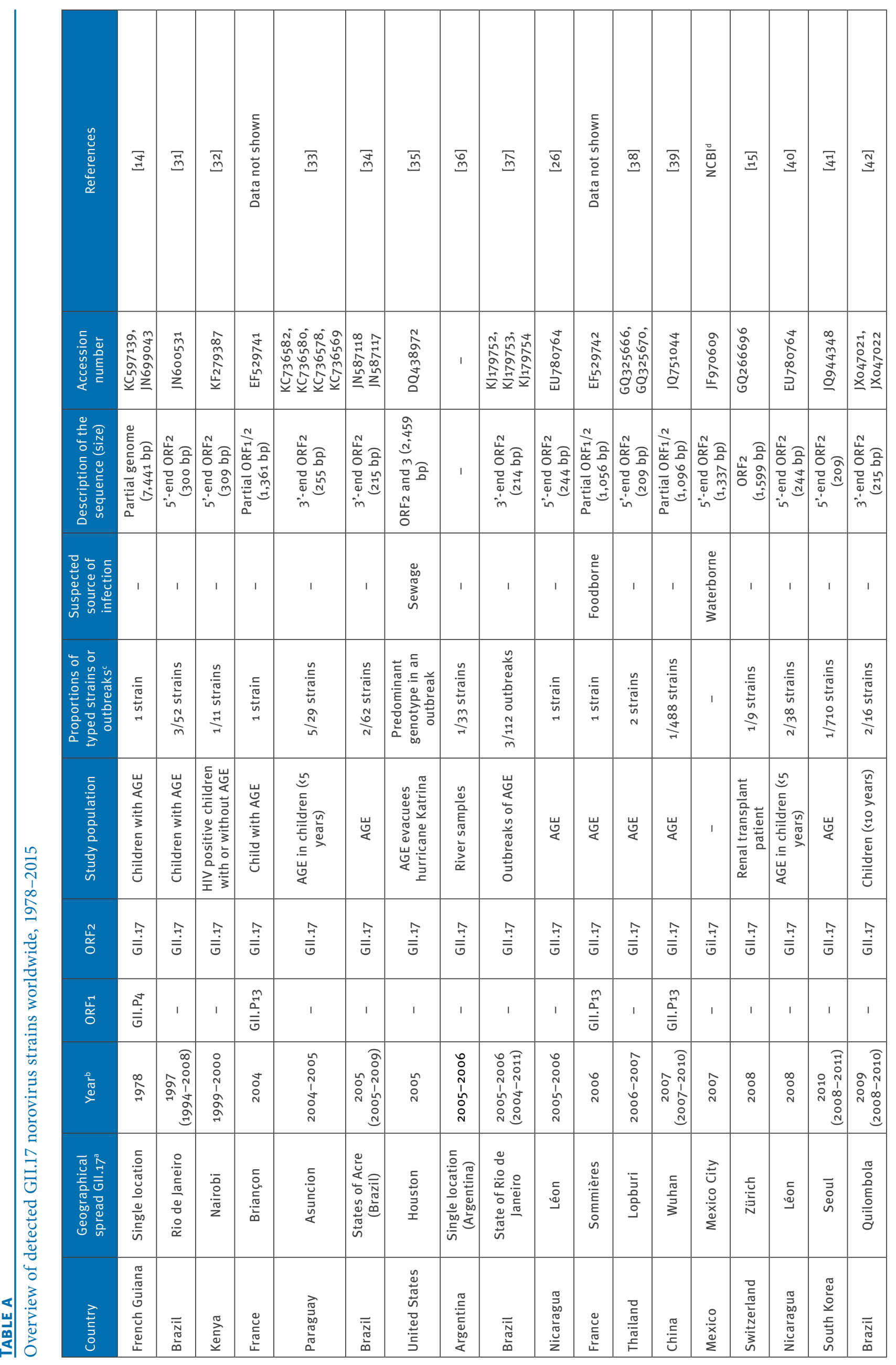




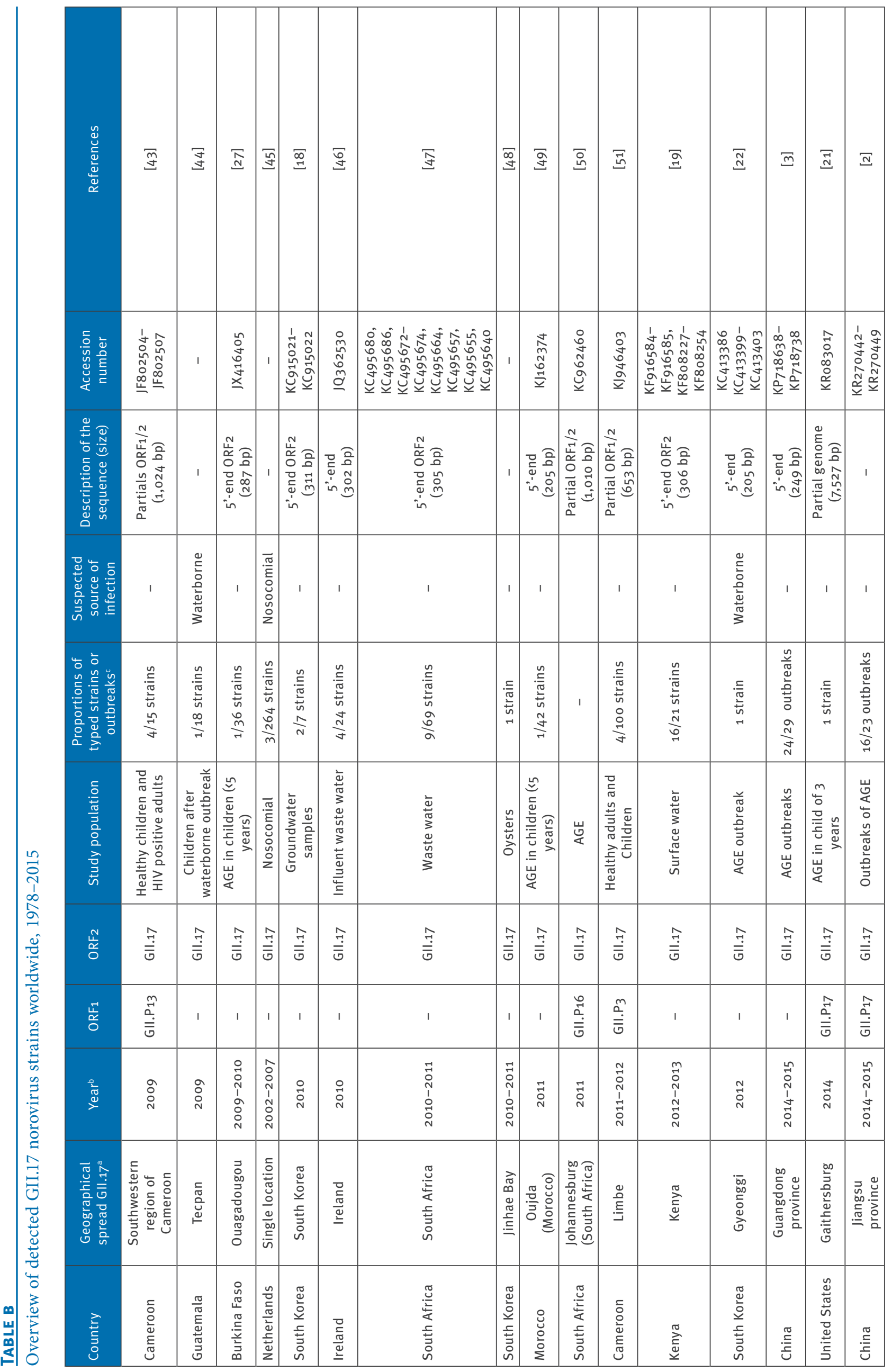




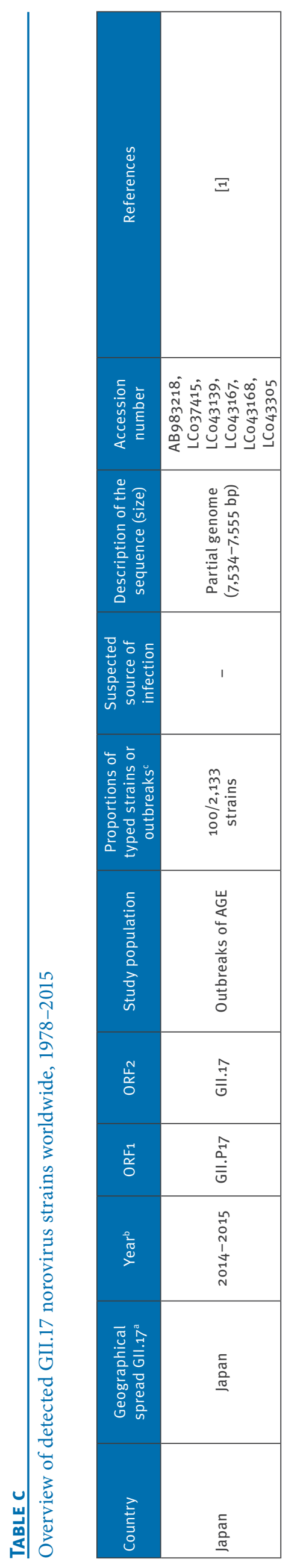

but since then, it has not resulted in an increase in AGE outbreaks as observed in China, nor replaced the predominant GII.4 in the last seasons (data not shown).

Based on sequence analyses of the ORF1-ORF2 junction region, most diagnostic real-time transcription polymerase chain reactions (PCRs) will be able to detect this novel Gll.17 virus, but it is not known whether the same holds true for immunoassays. However, only a small portion of norovirus outbreaks are typed beyond the GI and GII classification, therefore it is possible that GII.17 is more prevalent than we currently suspect.

\section{Phylogenetic analyses and molecular characterisation of the novel GII.17 viruses} Phylogenetic analysis of the viral protein 1 (VP1) of Gll.17 strains in the NCBI database demonstrated at least two clusters, with the novel Asian GIl.17 strains grouping together with the GIl.17 strains detected in the surface water in Kenya (Figure 2,[21]) and in an outbreak in 2012 in Korea [22]. Although the novel GIl.17 clusters away from previously identified GII.17 strains, the amino acids changes in VP1 are not sufficient to separate it into a different genotype. For only a limited number of Gll.17 strains the full VP1 has been sequenced, which demonstrated three deletions and at least one insertion compared with previous Gll.17 strains (comprehensive alignments are given in Fu et al. and Parra et al. $[2,21])$. The majority of these changes could be mapped in or near major epitopes of the VP1 protein and potentially result in antigenic drift or altered receptor-binding properties [21]. Most publicly available GIl.17 sequences only comprise the VP1, and most frequently the $5^{\prime}$-end of VP1 (C region), while most of the observed diversity within the GIl.17 genotype is observed in the 3'-end of VP1 (D region) [23].

Previously, viruses with a GIl.17 VP1 genotype contained a GII.P13 ORF1 genotype, although recombinants with an ORF1 GII.P16, GII.P3 and GII.P4 genotype have also been identified (Table). Sequence comparison showed that the ORF1 region of the novel GIl.17 viruses was not detected before and cluster between GII.P3 and GII.P13 viruses [21]. Since this is the first orphan ORF1 sequence associated with GIl.17, it has been designated GII.P17 according to the criteria of the proposal for a unified norovirus nomenclature and genotyping [24]. The novel GIl.17 virus was termed Kawasaki 2014 after the first near complete genome sequence (AB983218) submitted to GenBank. Noronet provides a publicly available and widely used tool for the typing of norovirus sequences (http://www.rivm.nl/mpf/ norovirus/typingtool). This typing tool was updated to ensure correct classification of both ORF1 and ORF2 sequences of the newly emerged GII.P17-GII.17 viruses.

The acquisition of a novel ORF1 could potentially result in an increase in replication efficiency and may - in part - explain the increase of the AGE outbreak activity. Histo-blood group antigens (HBGAs) function as (co-) receptors for noroviruses. Alpha(1,2)fucosyltransferase 
Unrooted maximum likelihood phylogenetic tree based on the 5'-end of virus protein 1 (VP1) sequences (C region) of GII.17 noroviruses, available from the National Center for Biotechnology Information (NCBI)

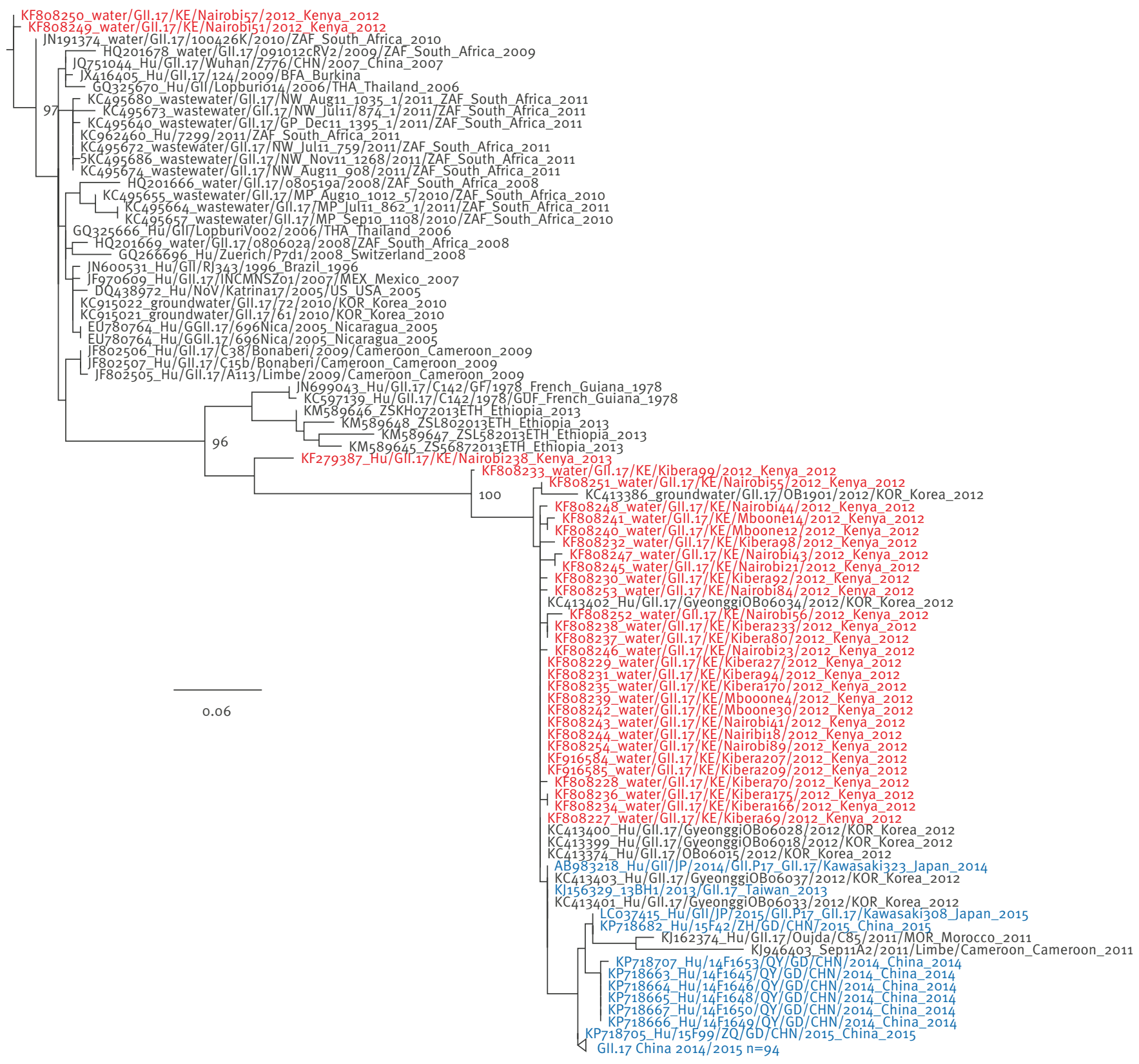

The tree was estimated under the general time reversible model using PhyML. Bootstrap values above $70 \%$ are given. Sequences from Kenya are depicted in red and those from the recent outbreaks (2013-1015) reported in Asia in blue. The scale bar represents nucleotide substitutions per site.

2 (FUT2) adds an alpha-1,2 linked fucose on HBGAs, and individuals lacking the FUT2 gene are referred to as 'non-secretors', while those with a functional FUT2 gene are called 'secretors'. Non-secretors have been shown to be less susceptible to infection with several norovirus genotypes [25]. In studies investigating the genetic susceptibility to norovirus genotypes, a secretor patient with blood type 0 Lewis phenotype $\mathrm{Le}^{\mathrm{a}-\mathrm{b}+}$ and a secretor patient with blood type B Lewis phenotype Le $\mathrm{Le}^{\mathrm{a}-\mathrm{b}}$ - were positive for previously identified Gll.17 viruses and no non-secretors were found positive $[26,27]$, suggesting that there could be genetic restrictions for Gll.17 viruses in infection of humans. How the observed genetic changes have affected the antigenic and binding properties of the novel GII.17 strains, and hereby the susceptible host population, remains to be discovered.

\section{Public health implications}

Based on the emergence and spread of new GIl.4 variants, we know that noroviruses are able to rapidly spread around the globe $[28,29]$. The novel GII.17 virus has been detected in sporadic cases throughout the world, but until now it has not resulted in an increase 
in outbreak activity or replacement of Gll.4 Sydney 2012 viruses outside of Asia. Following the patterns observed in the past years for Gll.4 noroviruses and based on the data from China and Japan, an increase in norovirus outbreak activity can be expected if the currently dominant GII.4 is replaced by GII.17. Another possibility - however - would be some restriction to global expansion, as has been observed previously for the norovirus variant Gll.4 Asia 2003 [29]. Such restrictions could be due to differences in pre-existing immunity, but could also be the result of differences between populations in the expression of norovirus receptors [29]. Based on current literature on the novel GII.17 virus there is no indication that it will be more virulent compared with GIl.4. Nevertheless, the public health community and surveillance systems need to be prepared in case of a potential increase of norovirus activity by this novel Gll.17 virus.

\section{Conclusions}

Understanding the epidemiology of norovirus genotypes is important given the development of vaccines that are entering clinical trials. Current candidate vaccines have targeted the most common norovirus genotypes, and it remains to be seen if vaccine immunity is cross-reactive with GII.17 viruses [30]. Contemporary norovirus diagnostic assays may not have been developed to detect genotype Gll.17 viruses since this genotype was previously only rarely found during routine surveillance. These assays need to be evaluated and updated if necessary to correctly diagnose norovirus outbreaks caused by the emerging Gll.17 virus. Norovirus strain typing ideally should include ORF1 sequences and the variable $\mathrm{VP}_{1}$ ' $D$ ' region as well as metadata on the host, like clinical symptoms, immune status and blood group. This will allow us to better study and monitor the genetic disposition, pathogenesis, evolution and epidemiology of this newly emerged virus.

\section{Acknowledgments}

We gratefully acknowledge the submitting laboratories of the sequences from the Noronet database. This work was supported by the EU H2020 grant COMPARE under grant agreement number 643476 and the Virgo Consortium, funded by Dutch government project number FESo908 and the Hungarian Scientific Research Fund (OTKA/NKFIH K111615). The findings and conclusions in this article are those of the authors and do not necessarily represent the official position of the Centers for Disease Control and Prevention (CDC).

\section{Conflict of interest}

None declared.

\section{Authors' contributions}

$M G$, JB, HV: compiling the data, drafting the manuscript; $A P, F B, K T, M C, J M, J N, G R, M L, L D R$, NI JH, VM, KAB, JV, PW: collecting field data, critical review of the manuscript; MK: initiation of study, providing data, critical review of the manuscript.
References

1. Matsushima Y, Ishikawa M, Shimizu T, Komane A, Kasuo S, Shinohara M, et al. Genetic analyses of GII.17 norovirus strains in diarrheal disease outbreaks from December 2014 to March 2015 in Japan reveal a novel polymerase sequence and amino acid substitutions in the capsid region. Euro Surveill. 2015;20(26): $\mathrm{pii}=21173$.

2. Fu J, Ai J, Jin M, Jiang C, Zhang J, Shi C, et al. Emergence of a new GII.17 norovirus variant in patients with acute gastroenteritis in Jiangsu, China, September 2014 to March 2015. Euro Surveill. 2015;20(24):21157. PMID:26111236

3. Lu J, Sun L, Fang L, Yang F, Mo Y, Lao J, et al. Gastroenteritis Outbreaks Caused by Norovirus GIl.17, Guangdong Province, China, 2014-2015. Emerg Infect Dis. 2015;21(7):1240-2. http:// dx.doi.org/10.3201/eid2107.150226 PMID:26080037

4. Atmar RL, Estes MK. The epidemiologic and clinical importance of norovirus infection. Gastroenterol Clin North Am. 2006;35(2):275-90, viii. http://dx.doi.org/10.1016/j. gtc.2006.03.001 PMID:16880066

5. Kroneman A, Harris J, Vennema H, Duizer E, van Duynhoven Y, Gray J, et al. Data quality of 5 years of central norovirus outbreak reporting in the European Network for food-borne viruses. J Public Health (Oxf). 2008;30(1):82-90. http://dx.doi. org/10.1093/pubmed/fdmo80 PMID:18089585

6. Wikswo ME, Hall AJ; Centers for Disease Control and Prevention. Outbreaks of acute gastroenteritis transmitted by person-to-person contact--United States, 2009-2010. MMWR Surveill Summ. 2012;61(9):1-12. PMID:23235338

7. Vinjé J. Advances in laboratory methods for detection and typing of norovirus. J Clin Microbiol. 2015;53(2):373-81. http:// dx.doi.org/10.1128/JCM.01535-14 PMID:24989606

8. Siebenga J, Lemey P, Kosakovsky Pond SL, Rambaut A, Vennema $\mathrm{H}$, Koopmans $\mathrm{M}$. Phylodynamic reconstruction reveals norovirus GII.4 epidemic expansions and their molecular determinants. PLoS Pathog. 2010;6(5):e1000884. http://dx.doi.org/10.1371/journal.ppat.1000884 PMID:20463813

9. Lopman B, Vennema H, Kohli E, Pothier P, Sanchez A, Negredo $A$, et al. Increase in viral gastroenteritis outbreaks in Europe and epidemic spread of new norovirus variant. Lancet. 2004;363(9410):682-8. http://dx.doi.org/10.1016/S01406736(04)15641-9 PMID:15001325

10. van Beek J, Ambert-Balay K, Botteldoorn N, Eden JS, Fonager J, Hewitt J, et al.; NoroNet. Indications for worldwide increased norovirus activity associated with emergence of a new variant of genotype II.4, late 2012. Euro Surveill. 2013;18(1):8-9. PMID:23305715

11. Lindesmith LC, Beltramello M, Donaldson EF, Corti D, Swanstrom J, Debbink K, et al. Immunogenetic mechanisms driving norovirus GII.4 antigenic variation. PLoS Pathog. 2012;8(5):e1002705. http://dx.doi.org/10.1371/journal. ppat.1002705 PMID:22615565

12. Eden JS, Tanaka MM, Boni MF, Rawlinson WD, White PA. Recombination within the pandemic norovirus Gll.4 lineage. J Virol. 2013;87(11):6270-82. http://dx.doi.org/10.1128/ JVI.03464-12 PMID:23536665

13. LC, Donaldson EF, Lobue AD, Cannon JL, Zheng DP, Vinje J, et al. Mechanisms of GII.4 norovirus persistence in human populations. PLoS Med. 2008;5(2):e31. http://dx.doi. org/10.1371/journal.pmed.0050031 PMID:18271619

14. Rackoff LA, Bok K, Green KY, Kapikian AZ. Epidemiology and evolution of rotaviruses and noroviruses from an archival WHO Global Study in Children (1976-79) with implications for vaccine design. PLoS ONE. 2013;8(3):e59394. http://dx.doi. org/10.1371/journal.pone.0059394 PMID:23536875

15. Schorn R, Höhne M, Meerbach A, Bossart W, Wüthrich RP, Schreier E, et al. Chronic norovirus infection after kidney transplantation: molecular evidence for immune-driven viral evolution. Clin Infect Dis. 2010;51(3):307-14. http://dx.doi. org/10.1086/653939 PMID:20575662

16. Vega E, Barclay L, Gregoricus N, Shirley SH, Lee D, Vinjé J. Genotypic and epidemiologic trends of norovirus outbreaks in the United States, 2009 to 2013. J Clin Microbiol. 2014;52(1):147-55. http://dx.doi.org/10.1128/JCM.02680-13 PMID:24172151

17. Verhoef L, Hewitt J, Barclay L, Ahmed SM, Lake R, Hall AJ, et al. Norovirus genotype profiles associated with foodborne transmission, 1999-2012. Emerg Infect Dis. 2015;21(4):592-9. http://dx.doi.org/10.3201/eid2104.141073 PMID:25811368

18. Lee BR, Lee SG, Park JH, Kim KY, Ryu SR, Rhee OJ, et al. Norovirus contamination levels in ground water treatment systems used for food-catering facilities in South Korea. Viruses. 2013;5(7):1646-54. http://dx.doi.org/10.3390/ v5071646 PMID:23820792 
19. Kiulia NM, Mans J, Mwenda JM, Taylor MB. Norovirus Gll.17 Predominates in Selected Surface Water Sources in Kenya. Food Environ Virol. 2014;6(4):221-31. http://dx.doi. org/10.1007/S12560-014-9160-6 PMID:25059212

20. TaipeiTimes. CDC probing strain of Taichung norovirus; 2015 . Available from: http://wwwtaipeitimescom/News/taiwan/ archives/2015/02/25/2003612208.

21. Parra IP, Green KY. Genome of Emerging Norovirus GII.17, United States, 2014. Emerg Infect Dis. 2015;21(8). http:// dx.doi.org/10.3201/eid2108.150652.

22. Cho HG, Lee SG, Kim WH, Lee JS, Park PH, Cheon DS, et al. Acute gastroenteritis outbreaks associated with groundwaterborne norovirus in South Korea during 2008-2012. Epidemiol Infect. 2014;142(12):2604-9. http://dx.doi. org/10.1017/S0950268814000247 PMID:24534556

23. Vinjé J, Hamidjaja RA, Sobsey MD. Development and application of a capsid $\mathrm{VP}_{1}$ (region $\mathrm{D}$ ) based reverse transcription PCR assay for genotyping of genogroup I and II noroviruses. J Virol Methods. 2004;116(2):109-17. http://dx.doi. org/10.1016/j.jviromet.2003.11.001 PMID:14738976

24. Kroneman A, Vega E, Vennema H, Vinjé J, White PA, Hansman $\mathrm{G}$, et al. Proposal for a unified norovirus nomenclature and genotyping. Arch Virol. 2013;158(10):2059-68. http://dx.doi. org/10.1007/s00705-013-1708-5 PMID:23615870

25. Lindesmith L, Moe C, Marionneau S, Ruvoen N, Jiang X, Lindblad L, et al. Human susceptibility and resistance to Norwalk virus infection. Nat Med. 2003;9(5):548-53. http:// dx.doi.org/10.1038/nm860 PMID:12692541

26. Bucardo F, Kindberg E, Paniagua M, Grahn A, Larson G, Vildevall M, et al. Genetic susceptibility to symptomatic norovirus infection in Nicaragua. J Med Virol. 2009;81(4):72835. http://dx.doi.org/10.1002/jmv.21426 PMID:19235844

27. Nordgren J, Nitiema LW, Ouermi D, Simpore J, Svensson L. Host genetic factors affect susceptibility to norovirus infections in Burkina Faso. PLoS ONE. 2013;8(7):e69557. http://dx.doi. org/10.1371/journal.pone.0069557 PMID:23894502

28. Eden JS, Hewitt J, Lim KL, Boni MF, Merif J, Greening G, et al. The emergence and evolution of the novel epidemic norovirus Gll.4 variant Sydney 2012. Virology. 2014;450-451:106-13. http://dx.doi.org/10.1016/j.virol.2013.12.005 PMID:24503072く/

29. Siebenga JJ, Vennema H, Zheng DP, Vinjé J, Lee BE, Pang $\mathrm{XL}$, et al. Norovirus illness is a global problem: emergence and spread of norovirus GII.4 variants, 2001-2007. J Infect Dis. 2009;200(5):802-12. http://dx.doi.org/10.1086/605127 PMID:19627248

30. Bernstein DI, Atmar RL, Lyon GM, Treanor JJ, Chen WH, Jiang $\mathrm{X}$, et al. Norovirus vaccine against experimental human GII.4 virus illness: a challenge study in healthy adults. J Infect Dis. 2015;211(6):870-8. http://dx.doi.org/10.1093/infdis/jiu497 PMID:25210140

31. Ferreira MS, Xavier MP, Tinga AC, Rose TL, Fumian TM, Fialho $A M$, et al. Assessment of gastroenteric viruses frequency in a children's day care center in Rio De Janeiro, Brazil: a fifteen year study (1994-2008). PLoS ONE. 2012;7(3):e33754. http:// dx.doi.org/10.1371/journal.pone.0033754 PMID:22448271

32. Mans J, Murray TY, Kiulia NM, Mwenda JM, Musoke RN, Taylor MB. Human caliciviruses detected in HIV-seropositive children in Kenya. J Med Virol. 2014;86(1):75-81. http://dx.doi. org/10.1002/jmv.23784 PMID:24123054

33. Galeano ME, Martinez M, Amarilla AA, Russomando G Miagostovich MP, Parra GI, et al. Molecular epidemiology of norovirus strains in Paraguayan children during 20042005: description of a possible new Gll.4 cluster. J Clin Virol. 2013;58(2):378-84. http://dx.doi.org/10.1016/j.jcv.2013.07.008 PMID:23932334

34. Fioretti JM, Ferreira MS, Victoria M, Vieira CB, Xavier MP, Leite JP, et al. Genetic diversity of noroviruses in Brazil. Mem Inst Oswaldo Cruz. 2011;106(8):942-7. http://dx.doi.org/10.1590/ So074-02762011000800008 PMID:22241115

35. Yee EL, Palacio H, Atmar RL, Shah U, Kilborn C, Faul M, et al. Widespread outbreak of norovirus gastroenteritis among evacuees of Hurricane Katrina residing in a large "megashelter" in Houston, Texas: lessons learned for prevention. Clin Infect Dis. 2007;44(8):1032-9. http://dx.doi. org/10.1086/512195 PMID:17366445

36. Fernández MD, Torres C, Poma HR, Riviello-López G, Martínez LC, Cisterna DM, et al. Environmental surveillance of norovirus in Argentina revealed distinct viral diversity patterns, seasonality and spatio-temporal diffusion processes. Sci Total Environ. 2012;437:262-9. http://dx.doi.org/10.1016/j. scitotenv.2012.08.033 PMID:22944218

37. de Andrade JS, Rocha MS, Carvalho-Costa FA, Fioretti JM, Xavier MP, Nunes ZM, et al. Noroviruses associated with outbreaks of acute gastroenteritis in the State of Rio Grande do Sul, Brazil, 2004-2011. J Clin Virol. 2014;61(3):345-52. http://dx.doi.org/10.1016/j.jcv.2014.08.024 PMID:25223919
38. Kittigul L, Pombubpa K, Taweekate Y, Diraphat P, Sujirarat D, Khamrin P, et al. Norovirus Gll-4 2006b variant circulating in patients with acute gastroenteritis in Thailand during a 20062007 study. J Med Virol. 2010;82(5):854-60. http://dx.doi. org/10.1002/jmv.21746 PMID:20336729

39. Wang YH, Zhou DJ, Zhou X, Yang T, Ghosh S, Pang BB, et al. Molecular epidemiology of noroviruses in children and adults with acute gastroenteritis in Wuhan, China, 2007-2010. Arch Virol. 2012;157(12):2417-24. http://dx.doi.org/10.1007/s00705012-1437-1 PMID:22886184

40. Bucardo F, Nordgren J, Carlsson B, Paniagua M, Lindgren PE, Espinoza F, et al. Pediatric norovirus diarrhea in Nicaragua. J Clin Microbiol. 2008;46(8):2573-80. http://dx.doi.org/10.1128/ JCM.00505-08 PMID:18562593

41. Park S, Jung J, Oh S, Jung $\mathrm{H}$, Oh $\mathrm{Y}$, Cho $\mathrm{S}$, et al. Characterization of norovirus infections in Seoul, Korea. Microbiol Immunol. 2012;56(10):700-7. http://dx.doi.org/10.1111/j.13480421.2012.00494.x PMID:22823184

42. Aragão GC, Mascarenhas JD, Kaiano JH, de Lucena MS, Siqueira JA, Fumian TM, et al. Norovirus diversity in diarrheic children from an African-descendant settlement in Belém, Northern Brazil. PLoS ONE. 2013;8(2):e56608. http://dx.doi.org/10.1371/ journal.pone.0056608 PMID:23457593

43. Ayukekbong J, Lindh M, Nenonen N, Tah F, Nkuo-Akenji T, Bergström T. Enteric viruses in healthy children in Cameroon: viral load and genotyping of norovirus strains. J Med Virol. 2011;83(12):2135-42. http://dx.doi.org/10.1002/jmv.22243 PMID:22012721

44. Arvelo W, Sosa SM, Juliao P, López MR, Estevéz A, López B, et al. Norovirus outbreak of probable waterborne transmission with high attack rate in a Guatemalan resort. J Clin Virol. 2012;55(1):8-11. http://dx.doi.org/10.1016/j.jcv.2012.02.018 PMID:22776162

45. Sukhrie FH, Beersma MF, Wong A, van der Veer B, Vennema $\mathrm{H}$, Bogerman J, et al. Using molecular epidemiology to trace transmission of nosocomial norovirus infection. J Clin Microbiol. 2011;49(2):602-6. http://dx.doi.org/10.1128/ JCM.01443-10 PMID:21159934

46. Rajko-Nenow P, Waters A, Keaveney S, Flannery J, Tuite G, Coughlan $S$, et al. Norovirus genotypes present in oysters and in effluent from a wastewater treatment plant during the seasonal peak of infections in Ireland in 2010. Appl Environ Microbiol. 2013;79(8):2578-87. http://dx.doi.org/10.1128/ AEM.03557-12 PMID:23396337

47. Murray TY, Mans J, Taylor MB. Human calicivirus diversity in wastewater in South Africa. J Appl Microbiol. 2013;114(6):184353. http://dx.doi.org/10.1111/jam.12167 PMID:23414393

48. Sin SB, Oh EG, Yu H, Son KT, Lee HJ, Park JY, et al. Genetic diversity of Noroviruses detected in oysters in Jinhae Bay, Korea. Food Sci Biotechnol. 2013;22(5):1453-60.

49. El Qazoui M, Oumzil H, Baassi L, El Omari N, Sadki K, Amzazi S, et al. Rotavirus and norovirus infections among acute gastroenteritis children in Morocco. BMC Infect Dis. 2014;14(1):300. http://dx.doi.org/10.1186/1471-2334-14-300 PMID:24894194

50. Mans J, Murray TY, Taylor MB. Novel norovirus recombinants detected in South Africa. Virol J. 2014;11(1):168. http://dx.doi. org/10.1186/1743-422X-11-168 PMID:25228444

51. Ayukekbong JA, Fobisong C, Tah F, Lindh M, Nkuo-Akenji T, Bergström T. Pattern of circulation of norovirus GII strains during natural infection. J Clin Microbiol. 2014;52(12):4253-9. http://dx.doi.org/10.1128/JCM.01896-14 PMID:25274996 